\title{
ADDRESSING THE PARADOX: COUNTERINSURGENCY, HUMAN RIGHTS AND WOMEN IN NORTHEAST NIGERIA
}

\author{
IBUKUN DAVID*
}

\begin{abstract}
Counterinsurgency (COIN) operations often result in widespread human rights violations because COIN operations are usually premised on the erroneous assumption of irreconcilable tension between human rights and national security. By reviewing narratives that frame official discourse on counterinsurgency and human rights in Nigeria as well as locating women at the heart of the debate, this essay argues that assumption of incompatibility between human rights and national security can explain the widespread rights violations associated with COIN operations against Boko Haram in northeast Nigeria. A gender-sensitive-right-based approach to COIN is therefore recommended.
\end{abstract}

Keywords: Insurgency, counterinsurgency, human rights, Northeast Nigeria, Boko Haram, women, national security

Summary: 1. Introduction. 2. Clarification of Concepts. 3. Women and the human Rights Cost of COUNTERINSURGENCY IN NORTHEAST Nigeria. 4. EXPlaining hUMAN RightS ViOlations in COIN OPERATIONS. 4.1. Literature review: the prevailing conceptual approach to COIN-human rights nexus. 4.2. Theoretical implications of the prevailing conceptual approach. 5. NigERIAN COIN FrAMEWORKS AND SUBORDINATION OF human Rights in COIN operations. 6. ReCOMmendation. 7. CONCLUSion.

\section{InTRODUCTION}

The present counterinsurgency (COIN) operations of the Nigerian state in the northeast of Nigeria can be linked to the violent insurgency of Jama'a Ahl asSunna Lida'wa wa-al Jihad, better known as Boko Haram. Historically, the Boko insurgency can be seen as part of Nigeria's long history of religious extremism and insurrectionary Islam that dates back to the Jihad led by Usman Dan Fodio in the late eighteenth century (see Hansen, 2020; Walker 2012; Loimeier 2012). At the base, it can be explained as part of the tradition in northern Nigeria of using Islam to justify insurrection against a corrupt ruling class (Hansen, 2020). There are however contestations about when exactly the group was established. For instance, while Loimeier (2012) claims that the group was formed in the early 1990s, Mongunu and Umara (2014) trace its origin to 2002. Despite the contestations surrounding the date of origin, there is a consensus in the literature that the group was founded by Mohammed Yusuf, a Maiduguri-based Islamic cleric (see Monguno and Umara 2014; Loimeier 2012).

During the early formative years, the activities of the group were centered chiefly on denouncing Nigeria's patrimonial governance system and promoting its vision of a society free of corruption (see Ladbury et al. 2016). Boko Haram however metamorphosed from a largely non-violent group under the leadership of Mohammed Yusuf into a violent insurgency that often adopts terrorist tactics under Abubakar Shekau starting from 2009.

* Department of International Relations, Obafemi Awolowo University, Ile-Ife, Nigeria (ibkdvd@gmail.com) 
Some scholars have therefore referred to the period before 2009 as the proselytizing stage of Boko Haram (see Kyari Mohammed, cited in Hansen, 2020, p. 8). Violence attributed to the group during this earlier stage was explained primarily as response to the heavy handedness of the secular state (see Hansen, 2020). Since 2009 when the group declared jihad against the Nigerian state, several high profile bombing attacks on both the state and the civilian population have been attributed to the group, and therefore prompting former president Goodluck Jonathan to appeal at the time that the group be designated an international terrorist organization. Some have located this violent twist in the activities of the group in the 2009 confrontation with security forces that led to killing of hundreds of its members and the arrest and subsequent death of its founder in controversial circumstances while in police custody (see Ladbury et al. 2016).

At the very core, Boko Haram is based on a radical Islamic ideology that is opposed to Western values and institutions (see Walker 2012; Loimeier 2012). Importantly, the group derives its name, Boko Haram (which literally means Western education is forbidden), from its rejection of Western values. Accordingly, Boko Haram primarily aims at preventing the spread of Western values and erecting in place a system based on Islamic sharia law all over Nigeria (see Ladbury et al. 2016). To achieve its objectives of creating an Islamic state in the country, Boko Haram draws on a narrative of resentment and vengeance against the secular authority of the state (see Blanchard and Cavigelli 2018). The attack on the UN building in Abuja in August 2011 could be interpreted as further reinforcing the group's ideology of opposition to Western values and institutions, especially if the UN is viewed as symbolizing Western values. Boko Haram came into national and international reckoning starting from 2010 when its activities assumed a more violent twist posing serious security and humanitarian challenges to Nigeria and its neighbors and indeed regional stability as a whole (see Buchanan-Clarke and Knoope 2017; Ladbury et al. 2016). The threat of the group as a terrorist organization has therefore become more imminent. Emblematic of the increasing awareness of the humanitarian threats of Boko is the abduction of over 270 Chibok school girls in Yobe State in April 2014.

While most scholarly works have conceptualized Boko Haram from the perspective of rejection of Western values, Thurston (2016) appeared to advance the argument that what is often interpreted as the group's ideology is in reality a fusion of two ideologies, namely: religious exclusivism and victimhood. Religious exclusivism would imply that Boko Haram is not only opposed to Western values, but that it is also opposed to alternative worldviews in the Muslim world or rival interpretations of Islam. Attacks on mosques by the group can only be understood within the context of this ideology of religious exclusivism. Thurston $(2016$, p. 5) further points out that, through its ideology of victimhood, Boko Haram claims that its violence is a response to what it sees as decadeslong history of persecution against Muslims in Nigeria:

They're holding our brothers in prison. They've arrested them, tortured them, and subjected them to various forms of abuse. I'm not just talking about our religious leader - now, they've started to detain our women... Since you are seizing our women, you wait and see what will happen to your women (Shekau, cited in Thurston 2016, p. 18). 
Although most of the group's violent activities have been restricted to Northeast of Nigeria, neighboring countries around the northern fringes, particularly in the Lake Chad region, have also suffered from the devastating effects of the violent activities of Boko Haram. It is generally recognized today that Boko Haram poses a threat beyond the national geography of Nigeria (Ladbury et al. 2016; Thurston 2016).

It is therefore worth emphasizing that the Boko Haram insurgency comes at a very high humanitarian cost for Nigeria and its neighbors. And it is clear that the efforts and significant achievements of the both the Nigerian armed forces and Multi-national Joint Task Force (MNTJF) in regaining territories from the group have not been enough to put an end to its activities. Buchanan-Clarke and Knoope (2017, p. 8) notes that attacks by the group has continued unabated, including suicide bombings, widespread sexual and gender-based violence (SGBV), kidnappings and forced recruitment, in Northeastern Nigeria and the Lake Chad region. Boko Haram has disrupted social life in the Northeast and left in its wake both internally and externally displaced. BuchananClarke and Knoope observe that an estimated 2 million people have been internally displaced in the Northeast of Nigeria since the beginning of the insurgency. Amnesty International (AI 2017) notes that 80 percent of the estimated 2 million displaced people live in host communities, while the rest live in Internally Displaced Persons (IDP) camps.

While the huge humanitarian cost and widespread human rights abuses associated with the activities of Boko Haram is well documented, scholarly attention to human rights violations resulting from COIN operations in the Northeast is still very scant. This is particularly true with efforts to understand how women in the Northeast experience COIN operations. This essay will not only fill these scholarly gaps, it will also hope to address the salient question of why COIN operations lead to violations of human rights, albeit from a gender-sensitive angle. This gender dimension becomes pertinent as women are often the primary victim of human rights abuses in violent conflict situations. Essentially, outbreak of violent conflicts exposes women to human rights violation (see Buvinic et al. 2012; Harders 2011; World Bank 2011; Schindler 2010; Lorber 2008; Anderlini 2006; Plumper and Neumayer 2006; Rehn and Sirleaf 2002; Date-Bah et al. 2001). Evidence abounds to show that women are more often the most vulnerable victims of violent conflicts. For instance, women are particularly exposed to gender-based and sexual violence (GBV) (see Bouta et al. 2005). Ultimately, violent conflicts often come at a very high cost for women. It is based on this realization that this essay examines the COIN-human rights nexus from the perspective of women in the Northeast of Nigeria. The paper however deviates from the traditional focus on rights violation by insurgents to interrogate rights violations by COIN forces and the civilians who collaborate with them in the operations against the insurgent Boko Haram.

\section{Clarification OF CONCEPTS}

Human rights: internationally recognized rights that every human being enjoys as an inalienable entitlement without discrimination. They are international moral principles that protect people in every part of the world against abuses. 
Women rights: international moral principles for protecting women against violation, including their sexual and reproductive rights and their rights not to be subjected to discriminatory and degrading treatments in time of peace and violent conflict.

COIN operations: refers to all military and humanitarian efforts deployed by the Nigerian state to address the Boko Haram insurgency in the northeast region of Nigeria. In this regard, COIN operations cover both military offensive against Boko Haram and defensive provision of security for internally displaced persons and camps by COIN forces. This definition is consistent with the Buhari Plan (2016: 21), which identifies security agencies as key partners in the management of IDP camps in the northeast.

COIN forces: made up of security and law enforcement agents of the state involved COIN operations in the northeast and their civilian collaborators, often referred to as civilian joint task force (Civilian JTF). According to the Buhari Plan (2016), their role also covers provision of security for IDP camps and communities affected by the insurgency.

Survivors: Persons and communities affected by the Boko Haram insurgency and resulting COIN operations.

National security: refers to a counterinsurgency and counter terrorism approach that emphasizes the survival of the state over the human rights of its citizens.

Policy: implies institutional frameworks and strategies of the state that are designed to counter security challenges in general and terrorism and insurgency in particular.

Policy makers: those responsible for the design and implementation of security and COIN strategies for the state.

\section{WOMEN AND THE HUMAN RIGHTS COST OF COUNTERINSURGENCY IN Northeast Nigeria}

Six states make up the Northeast geopolitical zone of Nigeria, and the states are namely: Adamawa, Bauchi, Borno, Gombe, Taraba, and Yobe (see UNDP 2017). The UNDP (2017) describes the Northeast as an agrarian region with an estimated population of around 18 million spread across the aforementioned states. Of the six states that make up the Northeast, the states of Borno, Yobe and Adamawa have suffered more from the violent insurgency of Boko Haram (see UNDP 2017; ACAPS 2017). Essentially, the Boko Haram insurgency has induced serious humanitarian crisis in the Northeast. To illuminate on the humanitarian situation in the region, the UNDP $(2017$, p. 4) reported that armed conflict:

has resulted in over 20,000 deaths, the forced displacement of over 2 million people, and the widespread loss of livelihoods ad access to essential social services. At the present, the humanitarian situation is rapidly approaching famine levels and is characterized by extreme levels of food insecurity, 
malnutrition and exposure to disease. Fourteen million people across the six states are estimated to have been affected by the conflict, with 8.5 million people in need of humanitarian assistance.

It reported further that in the three worst-affected states:

5.1 million people are currently in food insecurity ...........1.2 million children under 5 and pregnant and lactating women are malnourished and an estimated 6.9 million people are vulnerable to disease in the absence of access to health (UNDP 2017, p. 4).

While the Boko Haram insurgency is generally recognized as the major source of armed conflicts and instability in the region, the role of the historic neglect and marginalization of the Northeast, relative to other regions of Nigeria, in aggravating the destructive impacts of the conflict has started receiving attention (see UNDP 2017). For instance, the UNDP noted that the region suffers from a structural fragility that severely circumscribed the resilience of both economic system and households to conflict-induced shocks (2017, pp. 4-6). In addition to the relative structural marginalization of the region, the harsh climatic condition that confronts the Northeast makes the people vulnerable to poverty (see UNHCR 2017). Despite the well acknowledged role of structural and environmental factors, many have argued that the insurgent activities of Boko Haram further expose the region to extreme poverty and deprivation through the disruption of economic life and food production (see Buchanan-Clarke and Knoope 2017). An OCHA report, as cited in ACAPS (2017), puts the number of people in need of Boko Haram-induced humanitarian assistance in the Northeast at an estimated 4.6 million people.

Amnesty International (April, 2015) provides a more gender-sensitive analysis of the humanitarian situation in the Northeast by revealing that over 2000 women and girls have been abducted by Boko Haram since the start of 2014, and that many of the abducted women and girls have been sent into sexual slavery and trained to fight. To underscore the severity of the impacts of the insurgency on women, Amnesty International (AI) notes that the Chibok girls that were kidnapped by Boko Haram were only a small proportion of women and girls kidnapped by the insurgent group. Amnesty reports further that most of the kidnapped women and girls were prepared for marriage to members of the insurgent group through indoctrination. This report is consistent with Bouta et al. (2005, p. 33) who already posited that sexual exploitations of women in particular tend to increase in conflict situations. Overall, the Boko Haram insurgency has come at a very high cost for the human rights of women in the Northeast and both the insurgents and COIN forces have been implicated (Amnesty International April 2015; Human Right Watch 31 Oct. 2016). However, violation of rights by the insurgents is not much of a surprise as human rights violations by COIN forces. While employing excessive force to create fears falls within the operational strategies of an insurgency, preventing rights violation ought to be the primary objective of COIN operations (see Burke-White 2004; van Kempen 2013). COIN operations are therefore not expected to lead to widespread violation of human rights as they have paradoxically resulted to in the Northeast. 
It is in light of this paradoxical relationship between expectation and outcome of COIN operations in the Northeast that this essay has focused on COIN-related human rights violations in the region, albeit with specific attention to the experience of women. Human Rights Watch (HRW) gives a clear insight into how COIN operations have aggravated the human rights of women in the Northeast in a 2016 report. According to HRW (31 Oct. 2016), security officials raped and sexually exploited women and girls displaced by the Boko Haram insurgency. The report further indicted the government and relevant authorities for failure to protect displaced women and girls from such abuses either by facilitating access to basic rights or sanctioning culpable security officials. The report by Human Rights Watch also documented how 43 women and girls in internally displaced persons (IDP) camps in Maiduguri, Borno State, were subjected to sexual abuse, including rape and exploitation (HRW Oct. 2016). According to HRW (Oct. 2016), four of the aforementioned victims of sexual abuse narrated how they were drugged and raped by security agents and men of the civilian JTF in IDP camps in (Baga, Bama, and Gwoza) Maiduguri, while 37 others were cases of sexual exploitation as they were reportedly coerced into sex by COIN forces through false marriage promises and material and financial assistance. HRW reports that many of the sexually exploited that got pregnant were abandoned to endure discrimination and stigmatization from other camp residents.

For most women in the Northeast, their experiences have evolved from being survivors of Boko Haram to being victims of rights abuses by security officials. For instance, HRW (31 Oct. 2016) reports how a July 2016 situational assessment of IPDs in the Northeast by NOIPolls (Ngozi Okonjo Iweala Polls) revealed that 66 percent of 400 displaced people in Adamawa, Borno, and Yobe states affirmed that displaced women and girls were sexually abused by camp officials, and COIN security personnel in particular. Interestingly, sexual abuses against women displaced by Boko Haram were not restricted to the security officials of the state. Vigilante groups, otherwise known as civilian JTF, working with the government forces were also actively involved in the act (see HRW Oct. 2016; AI 2017). According to HRW most of the abused women and girls reported feelings of powerlessness and fear of retaliation stopped them from reporting cases of sexual abuse by security officials. At the Dikwa IDP camp in Bono State, HRW captures the experience of women who have been sexually abused by COIN forces that are charged with the security of IDP camps and communities ravaged by the insurgency in the Northeast thus:

One day he (a policeman) demanded to have sex with me," she said. "I refused but he forced me. It happened just that one time, but soon I realized I was pregnant. When I informed him about my condition, he threatened to shoot and kill me if I told anyone else. So I was too afraid to report him (HRW Oct. 2016).

Beside reported cases of rape, most women displaced by the Boko Haram insurgency became victims of sexual exploitation. Both rape and sexual exploitation fall under what most authors have classified as sexual and gender-based violence (SGBV) (see Buvinic 2012; Bouta et al. 2005). Sex for basic sustenance became part of the coping strategies most women were forced to adopt. According to HRW (Oct. 2016), COIN forces charged with providing security in IDP camps used their positions of authority and gifts 
of desperately needed food or other items to have sex with women. These women were left with no choice but to succumb to such advances as they already lost every means of livelihood to the insurgency. More so, IDP camps residents often narrated stories of food shortages. In one particular instance, HRW reported how a woman accepted the advances of a soldier who proposed marriage to her because she needed help in feeding her four children. HRW captures the experience of the sexually exploited woman thus:

The soldier showed his interest by bringing me food and clothes. He used to wear the green army uniform and carried a gun. I accepted him because I needed help to take care of me and my four children. Feeding in the camp is only once a day so you have to accept any help that comes. We started having sex in my camp tent - my sister who was sharing it with me left - or at night in the open field where soldiers stay in the camp. Five months later when I realized I was pregnant and told him, he stopped coming. I have not seen him since then. I feel so ashamed because my neighbors talk and stare at me. I cry whenever I think about him. I delivered the baby two months ago but he is also suffering - I eat once a day so [am] not producing enough milk to breast feed him well. Things are so bad in the camp, there is not enough water or food (HRW Oct. 2016).

For most of these women, their experience and role transformed from being housewives to being family breadwinners simply because most of them already lost spouses to the insurgency. This is consistent with the views of Date-Bah et al. (2001) that violent conflicts often result in an increase in the number of female-headed households. In noting that households headed by women had higher incidence of poverty and extreme poverty when compared with households headed by men, Schindler (2010) has drawn attention to some of the challenges that potentially confront female-headed households. Life, for most of the women in IDP camps, was a choice between conceding to sexual advances from security men or risk starvation. As noted by Amnesty International (May 2018), instead of receiving protection from the authorities, women and girls have been forced to succumb to rape in order to avoid starvation or hunger. According to a recent report by Amnesty International:

Scores of women described how soldiers and Civilian JTF members have used force and threats to rape women in satellite camps, including by taking advantage of hunger to coerce women to become their "girlfriends", which involved being available for sex on an ongoing basis (AI May 2018).

Rape and sexual exploitation of women in IDP camps were also reported at the Bama Hospital camp, where women were reportedly collected by civilian JTF members and taken to their quarters for sex (AI, March 2018).

Beyond exposing women to sexual exploitation and abuse, the Boko Haram insurgency also exposed them to sexually transmitted diseases and in the face of limited access to proper healthcare. This higher exposure to sexually transmitted diseases has been attributed to the relatively higher vulnerability of women to Sexual and Gender 
Based Violence (SGBV) (see Bouta et al. 2005). HRW (Oct. 2016) notes how a medical health worker at the Dikwa IDP camp in Maiduguri revealed a sharp increase in the number of people in need of treatment for HIV and other sexually transmitted diseases in that particular camp between when it was established in 2014 and 2016. Specifically, HRW observes that cases in need of treatment increased from 200 to 500 people within the aforementioned period at the aforementioned camp. Concerns have also been expressed that more women could be infected, with many of them too ashamed to go to the clinic (HRW Oct. 2016).

The experience of women in the hand of COIN forces has further reinforced the view that COIN operations often lead to violations of human rights. However, what still remain largely controversial, at least from the Nigerian context, is the salient question of why COIN operations lead to widespread human rights abuses.

\section{EXPLAINING HUMAN RIGHTS VIOLATIONS IN COIN OPERATIONS}

It is paradoxical that COIN leads to human rights violations though it is meant to prevent rights violation. This essay argues that this paradox results from the assumption underlying most COIN strategies and operations. Essentially, the paper argues that most COIN operations are framed by an assumption of a mythical irreconcilable tension between national security and human rights of individuals despite the usual proclamation by military authorities that rights promotion is at the heart of COIN. The aforementioned assumption is a dangerous myth, as it encourages subjugation of human rights goals for national security imperatives. Consequently, as emblematic in the COIN operations in northeast Nigeria, human rights promotion is treated as a means rather than as the core objective of all COIN and security strategies.

\subsection{Literature review: the prevailing conceptual approach to COIN-human rights nexus}

Drawing on the experience of the United States, Burke-White (2004) notes that human rights and national security are often viewed as mutually exclusive goals such that you can only promote human rights at the expense of national security. Almqvist (2005) notes, in this context, that human rights and security are commonly known as contending values. In other words, existing conceptualizations casts the relationship between human rights and national security in terms of "a winner-takes-all" competition and irreconcilable tension. One is therefore compelled to choose between security and human rights (Prezelj, 2015, p. 149). This way of understanding the relationship between human rights and national security creates an artificial and false dichotomy between the two goals that underpins the belief that human rights have no place in insurgency (see Ibrahim, 2015).

In effect, measures designed to counter terrorism, as well as insurgency, often challenge human rights, as some of these measures are usually laced in the belief that observance of human rights provisions aid terrorists but hinder states from fighting terrorism effectively (Almqvist, 2005; Warbrick, 2004). These measures are usually 
premised on the assumption that fighting terrorism effectively necessitates radical human rights trade-off Monnet and Bigo (2018) appear to advance similar argument when they observed that the war against terror is often based on the claim of a political imperative to act quickly and effectively against terrorism.

Overall, prevailing conceptualizations among those who design COIN measures converge around a conceptual approach that understands the link between COIN and human rights in terms of irreconcilable tension (see Monnet and Bigo, 2018; Carames and Fernandez 2017; Ibrahim, 2015; Prezelj, 2015; Almqvist, 2005; Burke-White, 2004; Warbrick, 2004).

\subsection{Theoretical implications of the prevailing conceptual approach}

As Burke-White (2004) points out, where human rights and national security are viewed to be in competition, national security considerations usually trump promotion of human rights $(2004$, p. 253). The currently prevailing understanding of COIN-human right nexus among policy-makers in terms of tension can therefore explain the widespread human rights violations that characterize most counter terrorism and COIN operations (see Prezelj 2015), including the counterinsurgency against Boko Haram in the northeast of Nigeria (Ibrahim, 2015).

The national security imperative of countering terror quickly and effectively often come with a demand by military authorities to modify human rights guarantees to the individual (Monnet and Bigo 2018). This form of demand is for Monnet and Bigo a detrimental simplification of the legal procedures from the viewpoint of those suspected or accused of terrorism. Studies have identified at least three important sources of tension between human rights and national security goals in the context of fighting terrorism (see Monnet and Bigo, 2018). First, tension can arise out of the political and strategic imperative to act quickly and effectively against terror, as this can stimulate demands for more powers to the state at the expense of human rights.

Second, fighting terrorism may result in the violation of privacy rights of individuals since it may demand relaxing limitations on surveillance of individuals suspected of terrorism (Monnet and Bigo 2018). For instance, following series of terrorist attacks across Europe in 2015 as typified in the Charlie Hebdo killings in France on 7 January of that year, the French Government, through declaration of a state of emergency on 14 November 2015, granted the state forces powers to search residences without warrant, in clear violation of the right to privacy. With the end of emergency rule on 1 November 2017, French authorities enacted new legislation widening the surveillance powers of the state in the fight against terrorism (see Monnet and Bigo, 2018). According to Monnet and Bigo (2018, p. 85) the new legislation has been criticized for granting excessive, vaguely defined and highly intrusive surveillance powers to law enforcement without adequate mechanisms of control and oversight. As Monnet and Bigo have shown, fighting terrorism catalyzed in France e not only the proposal of a system of interference with the right to respect for privacy but also a system of discrimination against migrants. 
Fighting terrorism can undermine the principle of presumption of innocence until found guilty by a competent law court. For instance, under the "US Military Order" that was issued by former US president Bush in November 2001, non-US citizens can be detained indefinitely without trial as part of the US war on terrorism. Similarly, Part 4 of the "UK Anti-Terrorism, Crime and Security Act" allows for indefinite administrative detention without trial in the name of fighting terrorism (Monnet and Bigo, 2018). Also, the Indian Armed Forces Special Power Act that was enacted to curtail insurgency in the northern part of India reportedly gives the armed forces the power to arrest individuals suspected of terrorism without warrant (see Almqvist, 2005). More concretely, the 2004 Human Rights Annual Report of the Foreign and Commonwealth Office of the UK noted and condemned human rights violations by US forces in the Abu Ghraib prison in Iraq, as well as the detention without trial of several individuals in the US Guantanamo Bay detention facilities in Cuba (see Almqvist, 2005).

\section{Nigerian COIN Frameworks AND SUbordination OF HUMAN RightS IN COIN OPERATIONS}

Beside the 1999 Constitution of the Federal Republic of Nigeria, relevant institutional frameworks for COIN operations in the northeast and Nigeria as a whole include: The Terrorism Prevention Amendment Act (2013); the National Action Plan for Preventing and Countering Violent Extremism (PCVE, 2017); and the National Security Strategy (NSS, 2019). While Section 1A (1) of the Terrorism Prevention Amendment Act (2013) empowers the Office of the National Security Adviser to coordinate all security and enforcement agencies in fighting terrorism in Nigeria, Section 1(2) of the amended Act charges the Attorney General of the Federation with the implementation and administration of the Act in line with extant international laws and best practices. Similarly, Section 1(3-6) of the Act specifies that the primary role of security and law enforcement agencies in the fight against terrorism is to enforce counter-terrorism legislations through the adoption of measures. The Act grants law enforcement agencies arbitrary powers that clearly suggest subordination of human rights to the national security imperatives of defeating insurgency. According to Section 25, sub-section 1(e) of the Act, law enforcement agents can arrest, search and detain any person whom the officer reasonably suspects to have committed or likely to commit an offence under this Act.

How to determine a reasonable suspicion is unclear and highly problematic, especially as the interpretation of what constitutes a reasonable suspicion may be arbitrary. Crucially, the Act did not specify what may constitute a reasonable ground for suspicion; this interpretation is left to the arbitrary interpretation of law enforcement agents. In the northeast, many have been subjected to detention without trial as well as extrajudicial killings as a result of the arbitrary powers conferred on law enforcement by the Terrorism Prevention Amended Act (2013). For instance, many, including 68 boys, were reportedly arrested and detained for several months at the Maiduguri Maximum Prison and Giwa Barracks without charges brought against them, based on suspicion of link to terrorism (Reliefweb, 29 April 2019). This arbitrary arrest was carried out as a reprisal by COIN forces on 14 March 2014, following Boko Haram attack on the military detention facility in Giwa Barracks in Maiduguri (AI, March 2018). 
The military reportedly killed at least 640 men and boys in this reprisal operation (AI, March 2018).

Within the framework of current conceptualization, the relationship between human rights and national security in the context of COIN in the northeast if Nigeria is also cast in terms of means-end analysis, where human rights promotion is merely seen as a means to the end of COIN operations. The PCVE (2017) is indicative of this form of means-end analysis. Although the PCVE makes human rights promotion a priority component in Nigeria's counterinsurgency, it is also clear that promotion of human rights is conceived in the PCVE (2017) as a means for the purpose of countering violent extremism rather than as the goal of COIN. Whereas the term human rights appeared on 15 separate occasions in the PCVE document, it was only referred to on a single occasion as the core objective of the PCVE (PCVE 2017, p. 12). In comparison, it was referenced as a guiding principle (a means) for achieving the goal of COIN in Nigeria on 12 occasions, and thereby suggesting an instrumental construction of human rights promotion. To underline this instrumental construction of human rights promotion in the prevailing COIN thinking in Nigeria, the PCVE (2017, p. 27) states that these actions (human rights promotion and the other priority components of the PCVE) will result in preventing grievances, which is one of the pathways leading to violent extremism. Essentially, the PCVE only promised to prioritize human rights in countering violent extremism (see PCVE 2017, p. 28). It did not promise to make human rights promotion the core goal of countering violent extremism. The policy implication of constructing human rights promotion as a means rather than the end in national security thinking in the context of COIN is that human rights promotion can be jettisoned for other means whenever the state thinks doing so would make fighting insurgency more effective. This has been the case in the northeast of Nigeria, where allegations of human rights abuses by COIN forces are often labelled a distraction to the national security goal of keeping the country together by the military.

In effect, Table 1 shows a comparative analysis of key concepts in the National Security Strategy 2019, using a word count to understand the weight given to respect for human rights and the rights of women in particular in the national security thinking of the Nigerian state relative to national security. This approach is consistent with the word frequency approach that is adopted in content analysis in political science (see Laver, Benoit, and Gary, 2003).

The word count reveals that the term "rights", in the context of human rights, only appeared on 12 occasions in the 80-page document. The word count further shows

Table 1: Word Count of Key Concepts in the National Security Strategy of Nigeria (NSS, 2019)

\begin{tabular}{|l|l|}
\hline Concepts & Frequency in the NSS \\
\hline Human rights & 12 \\
\hline Women (women rights) & $19(18)$ \\
\hline Security & 83 \\
\hline
\end{tabular}

Source: Author's analysis of NSS (2019) 
that direct reference was made to women on 19 occasions, with only 18 of the references addressing the human rights of women. Although the national security strategy that was enshrined in 2019 promises to address the security needs of women in Nigeria by outlining a number of steps to facilitate the actualization of this goal under the caption of gender sensitivity and security (see Chapter 6 of the NSS 2019, p. 47-8), it fails to identify these security needs and the specific sources of threats to the security of women, particularly in situations of outbreak of violent conflicts.

This omission implies Nigeria misses the opportunity to address women rights violations by COIN forces. And this is despite the national security document acknowledging that women along with children constitute the largest population of internally displaced in terrorism affected areas in Nigeria (see NSS 2019, p. 48). Overall, the NSS fails to adequately identify human rights violation as a national security concern. It therefore appears that the NSS (2019) only pays a superficial attention to human rights and the rights of women in particular. The superficiality of the attention given to human rights and the rights of women becomes glaring when compared with the repeated emphasis on national security in the 2019 NSS document revealed by the word count (see Table 1). Specifically, Table [1] reveals that the term national security appeared on 83 different occasions in comparison to an aggregate of 30 references to human and women rights. The frequent reference to national security relative to the two concepts of human rights and women rights can be viewed as a subordination of the latter to the former in a meansend relationship as indicated in the PCVE (2017). This form of relegation of human and women rights to national security imperatives can further encourage the violation of the rights of women, by both insurgents and COIN forces, in areas affected by the insurgency in the northeast of the country.

Although there are several official declarations by the Nigerian military authorities to the effect that human rights is not a distraction but a sine qua non in the conduct of counterinsurgency operations (see Olonisakin 2015), the attitude of the military to human rights in actual practice shows very low, if any, regard for human rights. For instance, The Chief of Army Staff, General Buratai, believes that allegations of human rights abuses against officers and men of the Nigerian Army are capable of demoralizing army personnel in the performance of their duties (Premium Times, 8 March 2017). As a further demonstration of subordination of human rights to national security imperatives, General Buratai urged judges to consider the aspect of national interest when handling cases of human rights abuses by members of the armed forces involved in COIN operations (see The Voice of Nigeria, 22 Nov 2018). According to Buratai, human rights cases instituted against the Nigerian Army are meant to distract the Army from carrying out its constitutional role of defending the territorial integrity of Nigeria (The Voice of Nigeria, 22 Nov 2018). Similarly, Human rights abuses associated with countering terrorism in Nigeria are sometimes described as military affair by the state. This is the type of explanation given by a presidential spokesperson to the deadly attacks by the men of the Nigerian Army that resulted to the death of several members of the Islamic Movement of Nigeria (MNI) in Zaria, Kaduna State, in December 2015 (see HRW, 22 December 2015). Statements and dispositions like those credited to the Chief of Army Staff can compromise objective investigation of allegations of rights abuses by COIN forces. 
Crucially, the military fails to maintain an open mind towards allegation of rights violations by its forces involved in the fight against insurgency. Consequently, rather than set in motion a transparent process of investigating and prosecuting allegations of rights violations by its forces, the Nigerian military authorities often follow a denial pathway. For example, Nossiter (3 June 2015) notes that official response to allegations of human rights violations by the military and other security agencies takes the form of consistent denial and downplaying of allegations as exaggerated. The Nigerian military often question the veracity of certain claims of human rights violations by COIN forces during counterinsurgency operations. For instance, the military maintains that, contrary to allegations of unlawful detention of suspects, the counterinsurgency in the northeast has resulted in the trial, conviction as well as release of several Boko Haram suspects (Defense Headquarters -DHQ- 23 Feb. 2018). In some instances, DHQ has argued that some of the reported cases of rights violations and figures of casualty were either unconfirmed or unsubstantiated. In other instances, the military has countered that some allegations of rights abuses are not consistent with provisions of the Nigerian Constitution. For example, DHQ argues that allegations of violations of the rights of lesbians, gays, bi-sexual and transgender (LGBT) are inconsistent with the Nigerian Constitution on those issues.

In this context, allegations of rights violations are denied as efforts to frustrate the fight against insurgency (see Hansen 2020). For example, Chris Olukolade, a former military spokesperson, followed this denial pathway by reportedly stating that allegations of human rights violations are unfortunate efforts aimed at undermining the army's resolve to defeat Boko Haram (Clottey 2015). Similarly, an army officer interviewed by Hansen (2020) denied allegations of rights abuses against COIN forces as false and aimed at destroying the reputation of the army in the fight against insurgency in the northeast. Despite this culture of denial by the military, Hansen (2020) notes that the evidence of rights violations by COIN forces is overwhelming.

This attitude of denial rather than constructive engagement of allegations of rights abuses can explain the widely reported characteristic failure of military authorities to investigate and prosecute allegations of human rights abuses by COIN forces. Where investigations are conducted, the process is usually not transparent and reports are rarely made public. For instance, the US Department of State (2019) cites the 2017 presidential investigative panel that was set up to investigate allegations of human rights abuses against the military. Crucially, it was found that though the panel submitted its findings early 2018, no parts of the report was made public and no one was held accountable for the rights violations that prompted the panel investigation (US Department of State 2019).

The failure of the military authority to prosecute and hold somebody accountable for the well documented human rights abuses by COIN forces in the northeast further clearly demonstrates the subordination of human rights to the national security goal of rooting the insurgents notwithstanding the cost to human rights. Overall, the nonprosecution of human rights offenders among COIN forces can be explained by a dilemma that confronts the Nigerian military authority: choosing between protecting its personnel involved in COIN operations and the human rights of civilians caught in the middle of the insurgency and counter-insurgency in the northeast. Olonisakin (2015), a Chief of Staff 
of the Nigerian Armed Forces, already draws attention to this dilemma by noting that the COIN operations in the northeast of Nigeria have three objectives that are difficult to achieve simultaneously. The three objectives include protection of COIN forces; observing respect for human rights under the principle of distinction; and elimination of insurgents. Olonisakin's testimony therefore reveals an irreconcilable conflict between protecting COIN forces and eliminating the insurgents on the one hand and protecting the human rights of individuals during COIN operations on the other hand. The conflict is irreconcilable because Olonisakin suggests that simultaneous pursuit of these three objectives usually entails a trade-off. And it is clear from observed human rights outcomes of COIN operations in the northeast that the national security goals of protecting COIN forces and eliminating the insurgents trump advancing the more sustainable goal and pathway to peace of respecting and protecting human rights of civilians caught in the middle of the insurgency in the northeast.

Olonisakin $(2015$, p. 3) echoes this sentiment of subordinating human rights to national security in noting that observing human rights norms in COIN operations is always a challenge for conventional forces pushed into overreacting by insurgent groups. Ultimately, human rights are viewed as obstacles to national security in the context of COIN operations in the northeast of Nigeria. Expectedly, COIN forces have been further encouraged and embolden to continue with rather than abandon the pattern of rights violations.

\section{ReCOMMENDATION}

This essay has demonstrated that it is not unusual for policymakers to construct the relationship between human rights and national security concerns in terms of an inherent tension and mutual antagonism. Constructions of this type have been shown to explain the subordination of human rights goals in most counterinsurgency operations. However, Burke-White (2004, p. 249) argues that the subordination of human rights to national security is both unnecessary and strategically questionable. For Burke-White, human rights and national security must be viewed as correlated and complementary. Almqvist (2005) therefore advances the argument that though tension may sometimes arise between the two values, this tension can be reconciled such that human rights come to occupy a central place in the security thinking of states. It is in this regard instructive to note that within the framework of UN global counterinsurgency strategy, human rights protection and effective counterinsurgency must be viewed as complementary goals that must be pursued together (UN 2008 p. 19).

While international humanitarian law recognizes the need to counter insurgency, it also requires states to undertake this critical task in ways that promote and protect human rights and fundamental freedom (UN 2013; UN General Assembly Res. 60/288 of $8 / 9 / 2006$ ). It is in this regard that counterinsurgency operations must operate within the framework of international human rights and humanitarian law (see Odomovo 2014). Although Article 4(1) of International Covenant on Civil Political Rights (ICCPR) allows states to derogate from observing human rights under condition of officially proclaimed public emergency that pose a threat to the life of the nation as long as doing this is not inconsistent with other obligations of the state under international law, Section 2 of the 
same Article 1 of ICCPR nevertheless stipulates that certain rights cannot be derogated. The implication of this latter provision of the ICCPR for COIN operations in the northeast of Nigeria is that there can be no justification for violating certain human rights of women. ICCPR lists the fundamental human rights that permit no derogation to include right to life (Art. 6); prohibition from being subjected to torture and inhumane treatment (Art. 7); right not to be subjected to slavery of any form (Art. 8); and right to liberty and security of person. The well-documented abuses COIN forces subject women in the northeast to are therefore serious infractions and crimes under both international human rights law and international humanitarian law.

Accordingly, Article 18 of the African Charter on Human and People's Rights (1986) prohibits all forms of discrimination against women, and it also guarantees the protection of the rights of women under relevant international declarations and conventions. While stipulating the rights of women to human dignity, Article $3(3 \& 4)$ mandate states to prohibit any exploitation and degradation of women as well as to take appropriate measures to protect women from all forms of violence and particularly sexual and verbal violence, such as women have been reportedly subjected to by COIN forces and their civilian collaborators in communities affected by insurgency and IDP camps hosting insurgency displaced people in the northeast of Nigeria. Subjecting women to rape and sexual assault is a serious violation of their rights to exercise control over their fertility, maternity and other sexual and reproductive rights guaranteed under Article 14 of the Maputo Protocol of 2003. Specifically, Article 11(3) stipulates that states have a responsibility to bring perpetrators of such acts (sexual violence and exploitation against women under situations of violent conflict) to justice before a competent court.

Similarly, the National IDPs Policy (2012) serves as a policy framework for protecting IDPs, particularly displaced women, in Nigeria against human rights violations. It not only pays special attention to the protection of displaced women, it also provides a framework for seeking redress and holding both state and non-state perpetrators accountable for the violation of the human rights of displaced women. And it is to this end guided by a set of gender-sensitive general and humanitarian principles. Accordingly, Section 3.1.5 of the National IDPs Policy (2012) provides a more women-specific protection for IDPs in Nigeria by prohibiting subjecting women in IDP camps to all forms of indignity, including sexual abuse and forced marriage. The National IDPs Policy (2012) of Nigeria therefore imposes upon the Nigerian state and governments at all levels responsibilities to: respect; protect; and fulfill the rights of displaced women in the northeast to security of their human rights (see National IDPs Policy 2012). Governments and other stakeholders must in this sense not only refrain from taking actions that may jeopardize the human rights of women, but they must also take deliberate actions to prevent violation by a third-party, and they must in addition create the enabling environments for IDPs to fully enjoy their rights without discrimination. The failure by the Nigerian military to therefore bring to justice men of the Nigerian armed forces that have been accused of sexual violence and exploitation against women in the northeast must be viewed as a major indictment for the Nigerian state.

Counterinsurgency is in this context no excuse for the gross violation of human rights, especially of women, that has been noted to be the hallmark of the fight against 
Boko Haram in the northeast of Nigeria. As Ibrahim (2015) puts it, there is nothing to be gained from trading Boko Haram's evil for military atrocities against civilians. To therefore underline the human rights protection imperatives of counterinsurgency operations, the UN (2011) goes beyond viewing the protection of human rights of victims of terrorism as a legal responsibility of the state to stipulating that states must not hide under the pretext of fighting terrorism or insurgency to violate human rights of people; especially of the supposed beneficiaries of such fight. Emphasizing also that states cannot bypass their obligations to ensure respect for human rights on the claims of national security, Monnet and Bigo (2018, p. 18) argue that human rights are not a luxury which can be disregarded depending on the type of threat a state encounters.

In effect, Office of High Commissioner for Human Rights (OHCHR 2008) posits that respect for human rights and the rule of law must be the bedrock of the global fight against terrorism. Accordingly, like several others, Warbrick (2004, p. 989) argues that the insistence on the applications and observance of human rights, even where modifications are necessitated under conditions of public emergence, must be an essential feature of any response to terrorism. COIN strategies and operations must in this regard not deviate from international human rights standards. This is because as van Kempen (2013) has argued: given that human rights protection constitutes security, any restriction on enjoyment of human rights would amount to a loss of security. Ultimately, human rights protection must be treated as the core goal of all COIN operations. The following are therefore proposed for addressing the widespread violations of human rights and women rights in the northeast:

- $\quad$ All cases of rights violation against women by COIN forces in IDP camps and communities affected by the insurgency in the northeast must be reopened for fresh and independent investigation and prosecution where necessary.

- The principle of transparency must be enshrined into the trial of cases of rights abuses in the COIN operations through the involvement of civil society actors.

- $\quad$ To give credibility to the trial process, cases of rights violations by COIN forces should be tried in civil courts of appropriate jurisdiction.

- Investment in citizenship education for women in IDP camps must be prioritized to increase their awareness about their fundamental human rights and where to get help in case of rights violation.

\section{Conclusion}

Experience from the counterinsurgency against Boko Haram in northeast Nigeria has shown that measures taken to tackle insurgencies can create serious human rights problems of their own, and that failure to acknowledge and constructively engage this possibility as part of the reality of counterinsurgency operations can further exacerbate rather than discourage human rights violations by COIN forces. Crucially, the paper showed that underlying most COIN strategies and operations is the assumption that there is an irreconcilable tension between human rights and national security goals. This 
assumption, the paper revealed, largely explains the subordination of human rights to national security imperatives as well as the consequent widespread violation of human rights during COIN operations. And given the gendered nature of armed conflicts, the experience from the northeast of Nigeria, as demonstrated in this essay, shows that women are especially vulnerable to rights violations by COIN forces. In this context, several documented cases of allegations of violation of the human rights of women in the Boko Haram-ravaged northeast of Nigeria by COIN forces and their civilian collaborators (CJTF) were revealed. Unfortunately, rather than constructively engage the several allegations, military authorities have either denied or downplayed such claims. In some extreme cases, allegations of human rights violations by COIN forces have been denounced by the military as deliberate designs to frustrate the COIN goal of defeating Boko Haram. The study concludes that changing the prevailing narrative of incompatibility between human rights and national security that frame existing COIN strategies will be central to addressing the widespread human rights violations that have become characteristic of the ongoing COIN in the northeast of Nigeria and elsewhere. In effect, a human right based approach that is sensitive to gender differences must inform all COIN strategies and operations. Ultimately, beyond viewing human rights and national security as complementary rather than competing in the context of COIN, human rights protection must be seen as the core goal of all COIN operations.

\section{REFERENCES}

ACAPS, (2017) “Northeast Nigeria Conflict: Secondary Data Review”, viewed 10 April 2019, from: http://www.acaps.org $>$ files $>$ files

African Charter of Human and Peoples' Rights (1986)

ALMQVIST, J, (2005) Rethinking Security and Human Rights in the Struggle against Terrorism, Paper Presented at the ESIL Forum in the Workshop on 'Human Rights under Threat' on 27 May 2005

Amnesty International, (2017) Nigeria 2016/2017, viewed 20 April 2020, from: https:// www.amnesty.org/en/countries/africa/nigeria/report-nigeria/

Amnesty International, 24 May (2018) They betrayed us: women who Survived Boko Haram Raped, Starved and Detained in Nigeria, Amnesty International, London

Amnesty International, March (2018) Nigeria: Still no Accountability for Human Rights Violations, Amnesty International Submission for the UN Universal Periodic Review, 31st Session of the UPR Working Group, November 2018

Amnesty International, 14 April (2015) Nigeria: abducted women and girls forced to join Boko Haram attacks, viewed 10 April 2019, from: https://www.amnesty.org/en/ latest/news//04/nigeria-abducted-women-and-girls-forced-to-join-boko-haramattacks/

ANDERLINI, SN, (2006) Mainstreaming Gender in Conflict Analysis: issues and Recommendations, Conflict Prevention and Reconstruction Unit of the World Bank, Washington DC, Working Paper No. 33 
BLANCHARD, LP \& CAVIGELLI, KT, (2018) Boko Haram and the Islamic State's West Africa Province, Congressional Reserve Service, In Focus

BOUTA, T, FRERKS, G \& BANNON, I, (2005) Gender, Conflict and Development, The World Bank, Washington DC

BUCHANAN-CLARKE, S \& KNOOPE, P, (2017) The Boko Haram insurgency: from Short Term Gains to Long Term Solutions, IJR, . Virginia, USA, Occasional Paper 23

BURKE-WHITE, WW, (2004) Human Rights and National Security: the Strategic Correlation, Harvard Human Rights Journal, vol. 17, pp. 249-80

BUVINIC, M, DAS GUPTA, M, CASABONNE, U \& VERWIMP, P, (2012) Violent Conflict and Gender Inequality: an Overview, Households in Conflict Network (HiCN), Brighton, UK, Working Paper 129

CARAMES, A (ed.) \& FERNANDEZ, J, (2017) Without rights there is not security: human rights violations in the Euro-Mediterranean region as a consequence of antiterrorist legislations. NOVACT

CLOTTEY, P, (2015) Nigerian Military Rejects International Report: interview with Major General Chris Olukolade, spokesman for Nigeria military, 3 June 2015, viewed 20 April 2020, from: https://www.voanews.com/africa/nigerian-militaryrejects-amnesty-international-report

DATE-BAH, E \& WALSH, M. et. al. (2001) Gender and Armed Conflicts: Challenges for Decent Work, Gender Equity and Peace Building Agendas, ILO, Geneva, Working Paper 2. viewed 10 April 2019, from: http://www-ilo-mirror.cornell.edu/public/ english/employment/recon/crisis/publ/wp2.htm

DHQ, 23 Feb. (2018) Re: Amnesty International Annual Report on Alleged Human Rights Abuse by the Nigerian Military, 23 February viewed 20 April 2020, from: https:// defenceinfo.mil.ng/re-amnesty-international-annual-report-on-alleged-humanrights-abuse-by-the-nigerian-military/\#disqus_thread)

HANSEN, W, (2020) The ugly face of the state: Nigerian security forces, human rights and the search for Boko Haram, Canadian Journal of African Studies/Revue canadienne des études africaines. DOI: 10.1080/00083968.2019.1700813

HARDERS, C, (2011) Gender Relations, Violence and Conflict Transformation. Berghof Foundation, Berlin, Germany

HRW, 22 December (2015) Nigeria Army attack on Shia unjustified, viewed 15 October 2020, from: https://www.hrw.org/news/2015/12/22/nigeria-army-attack-shia-unjustified

HRW, (2016) Nigeria: officials Abusing Displaced Women, Girls: displaced by Boko Haram and Victims Twice Over, 31 October, viewed 10 April 2019, from: https:// www.hrw.org/news/2016/10/31/nigeria-officials-abusing-displaced-women-girls

IBRAHIM, M, August (2015) Counter-Insurgency: is human rights a distraction or sine qua non? Paper presented at the 55th session of the Nigerian Bar Association 
conference, Amnesty International Nigeria, 25 August, viewed 20 April, from: https://www.refworld.org>pdfid

LADBURY, S, ALAMIN, H, NAGARAJAN, C, FRANCIS, P \& UKIWO, U, (2016) Jihadi groups and state-building: the case of Boko Haram in Nigeria, Stability: International Journal of Security \& Development, vol. 5, no. 1, pp. 1-19, DOI: http://dx.doi.org/10.5334/sta.427

LAVER, M, BENOIT, K, \& GARRY, J, (2003) Extracting policy positions from political texts using words as data, American Political Science Review, vol. 97, pp. 311-331.

LOBER, J, 2008, 'Constructing Gender: the Dancer and the Dance' in JA Holstein and JF Gubrium (eds.), Handbook of Constructionist Research, Guilford Press, New York, pp. 531-44

LOIMEIER, R, (2012) 'Boko Haram: the Development of a Militant Religious Movement', Africa Spectrum, vol. 47, pp. 137-155

MONGUNO, AK \& UMARA, I, (2014) Why Borno? History, geography and society in Islamic radicalization, NSRP Project on Radicalization, Counter-Radicalization and De-radicalization in northern Nigeria, Abuja

MONNET, J \& BIGO, D, (2018) Anti- \& Counterterrorism and Human Rights in Europe: 5 Snapshots of Current Controversies, Queen Mary University School of Law, London

National IDP Policy (2012) National Policy on Internally Displaced Persons (IDPS) in Nigeria

NOSSITER, A, (2015) Abuses by Nigeria's Military Found to Be Rampant in War Against Boko Haram, The New York Times, 3 June, viewed 20 April 2020, from: https:// www.nytimes.com//06/04/world/africa/abuses-nigeria-military-boko-haramwarreport.html

NSS (2019) National Security Strategy of the Federal Republic of Nigeria

ODOMOVO, AS, (2014) 'Insurgency, counter-insurgency and human rights violations', The Age of Human Rights Journal, vol. 3, pp. 46-62

OHCHR, (2008) Human Rights, Terrorism and Counter-terrorism, Office of the United Nations High Commissioner for Human Rights, Geneva, Fact Sheet No. 32

OLONISAKIN, A, (2015) Counterinsurgency: Is the Quest for Human Rights a Distraction or Sine Qua Non?, viewed 20 April 2020, from: https://s3-eu-west-1.amazonaws .com/nbaagc/papers/Sessions_Files/Counter_Insurgency_Session/General+AG+ Olonisakin+PAPER $\% 2 \mathrm{C}+$ Chief + of + Defence+Staff.pdf $>$

PCVE (2017) Federal Republic of Nigeria Policy Framework and National Action Plan for Preventing and Countering Violent Extremism 
PLUMPER, T \& NEUMAYER, E, (2006) 'The unequal burden of war: The effect of armed conflict on the gender gap life expectancy', International Organization, Summer, pp. 723-54

PREZELJ, I, (2015) 'Relationship between security and human rights in counter-terrorism: a case of introducing body scanners in civil aviation', International Studies Interdisciplinary Political and Cultural Journal, vol. 17, no. 1, pp. 145-158

Premium Times, 8 March (2018) Amnesty International Report: Nigerian Army sets up committee to investigate rights violations, viewed 15 October 2020, from: https:// www.premiumtimesng.com/news/top-news/225572-amnesty-international-report -nigerian-army-setscommittee-investigate-rights-violations.html

REHN, E \& SIRLEAF, EJ, (2002) Women, War and Peace: The Independent Expert's Assessment on the Impact of Armed Conflict on Women and Women's Role in Peace-Building, UNIFEM, New York

RELIEFWEB, 29 April (2019) Nigeria: Children and women face sexual violence in Borno prisons, viewed 15 October 2020, from: https://reliefweb.int/report/nigeria/ nigeria-children-and-women-face-sexual-violence-borno-prisons

SCHINDLER, K, (2010) Who Does What in a Household after Genocide? Evidence from Rwanda, DIW, Berlin, Discussion Papers 1072

Terrorism (Prevention) (Amendment) ACT, 2013 of the Federal Republic of Nigeria

The Buhari Plan 2016 for Rebuilding the North East

The Maputo Protocol 2003 Protocol to the African Charter on Human and Peoples' Rights on the Rights of Women in Africa

The Voice of Nigeria, 22 Nov (2018) Human Rights Violations Suits Against Nigerian Army Meant to Distract Her Constitutional Role... Buratai, viewed 15 October 2020, from: https://www.google.com/amp/s/www.thenigerianvoice.com/amp/news/2 72919/human-rights-violations-suitsagainst-nigerian-army-meant-to.html

THURSTON, A, January (2016) The disease is unbelief: Boko Haram's religious and political worldview, The Brookings Project on US Relations with the Islamic World, Washington DC, Analysis Paper No. 22

UNDP, (2017) Case Study: Famine Response and Prevention in North-East Nigeria, United Nations Development Program, New York

UNHCR, (2017) Nigeria 2017 Regional Response Plan, January-February, viewed 10 April 2019, from: http://reporting.unhcr. org/node/16433

United Nations, (2006) United Nations Global Counter-Terrorism Strategy, Resolution $60 / 288$ adopted by the General Assembly at the 60th Session on 8 September, viewed 20 April 2020, from: http://daccess-dds-ny.un.org/doc/UNDOC/GEN/ N05/504/88/PDF/N0550488.pdf?OpenElement

United Nations, (2008) Human Rights, Terrorism and Counter-terrorism, Office of the United Nations High Commissioner for Human Rights, New York, Factsheet 
No.32, viewed 20 April 2020, from: http://www.ohchr.org/Documents/Publicati ons/Factsheet32EN.pdf

United Nations (2011) Statement by the Special Rapporteur on the Promotion and Protection of Human Rights while Countering Terrorism at the 66th Session of the General Assembly, New York, 20 October. Retrieved April 20, 2020, from: http://www.ohchr. org/EN/NewsEvents/Pages/Display/News.aspx?NewsID=11736\&LangID=E

United Nations, (2013) Report of the Special Rapporteur on the Promotion and Protection of Human Rights and Fundamental Freedoms while Countering Terrorism, presented at the 68th Session of the General Assembly, 18 September, viewed 20 April 2020, from: http://justsecurity.org/wpcontent/uploads/2013/10/2013Emmer sonSpecialRapporteurReportDrones.pdf

US Department of State, (2019) Country Reports on Human Rights Practices: Nigeria, Bureau of Democracy, Human Rights, and Labor, viewed 20 April 2020, from: https://www.state.gov/reports/2019-country-reports-on-human-rights-practices/nig eria/

VAN KEMPEN, PH, (2013) 'Four Concepts of Security: A Human Rights Perspective', Human Rights Law Review, vol. 13, no. 1, pp. 1-23

WALKER, A, (2012) What is Boko Haram? United States Institute of Peace, Washington DC, Special Report

WARBRICK, C, (2004) 'The European Response to Terrorism in an Age of Human Rights', The European Journal of International Law, vol. 15, no. 5, pp. 989-1018

WORLD BANK, (2011) World Development Report 2011: Conflict, Security and Development, The World Bank, Washington DC

Received: June $18^{\text {th }} 2020$

Accepted: August $14^{\text {th }} 2020$ 